Indonesian Journal of Biotechnology, June, 2015

Vol. 20, No. 1, pp.77-87

\title{
Identification of BSA B1 Bacteria and Its Potency of Purified Cellulase to Hydrolyze Chlorella zofingiensis
}

\author{
Rifqi Zahroh Janatunaim ${ }^{1}$, Radhiyah Mardhiyah Hamid ${ }^{1}$, Ghea Putri Christy ${ }^{1}$, Yekti \\ Asih Purwestri ${ }^{1}$, Woro Anindito Sri Tunjung ${ }^{1 *}$
}

${ }^{1}$ Laboratory of Biochemistry , Faculty of Biology, Universitas Gadjah Mada, Jl. Teknika Selatan, Sekip Utara, Yogyakarta 55281, Indonesia.

\begin{abstract}
Cellulase has been widely used as biocatalyst in industries. Production of cellulase from microorganisms has many advantages such as short production time and less expense. Our previous study indicated that one of cellulolytic bacteria from digestive tract of milkfish (Chanos chanos), namely BSA B1, showed the highest cellulase activity. The objective of this study was to determine the phylogenetic of BSA B1 strain using 16S rRNA gene sequence. Furthermore, this study also determine the specific activity of purified cellulase from BSA B1 strain and its potency to hydrolyze Chlorella zofingiensis cellulose. Cellulase was purified using ammonium sulphate precipitation, dialysis, and ion exchange chromatography. The purified cellulase was used to hydrolyze cellulose of C. zofingiensis. The result demonstrated that BSA B1 strain was closely related with Bacillus aerius and Bacillus licheniformis. The specific activity of the crude enzyme was $1.543 \mathrm{U} \mathrm{mL}^{-1}$; after dialysis was $4.384 \mathrm{U}$ $\mathrm{mL}^{-1}$; and after chromatography was $7.543 \mathrm{U} \mathrm{mL}^{-1}$. Purified cellulase exhibited activity in hydrolyzed both CMC and C. zofingiensis. Compared to commercial cellulase, purified cellulase had lower activity in hydrolyzed CMC but higher activity in hydrolyzed C. zofingiensis. Ethanol dehydration could potentially increase the reducing sugar yield in cellulose hydrolysis when used appropriately. Morphology of $C$. zofingiensis cell has changed after incubation with cellulases and ethanol dehydration indicated degradation of cell wall.
\end{abstract}

Keywords: cellulase, enzyme purification, cellulose hydrolysis, BSA-B1

\section{Introduction}

Cellulase is the hydrolase enzyme that has been widely used as biocatalyst in various industries.

The uses of cellulase have been reaching $20 \%$ of the whole use of enzymes in the world (Mantyla et al. 1998). Cellulase can be used as biocatalyst in the process of composting organic waste and the production of bioethanol or biofuel from materials containing cellulose (Hidayanti, 2011).

Nowadays, single cell protein (SCP) has been developed especially in the

\section{*Corresponding author:}

Woro Anindito Sri Tunjung

Laboratory of Biochemistry, Faculty of Biology Universitas Gadjah Mada, Yogyakarta 55281, Indonesia. Email : wanindito@ugm.ac.id, Phone: (0274) 580839, Fax.: (0274) 580839 agricultural sector for the provision of quality feed and increased food quality. The SCP and bioethanol can be developed from microalgae, one of them is Chlorella. However the degradation of cellulose into bioethanol and SCP is still difficult because the algae have more complex cellulose cell wall structure. Degradation of cellulose in the cell wall of Chlorella can be done by an enzymatic reaction using pure cellulase like cellulase R-10, Y-23 pektiolase, pectinase, maserosim, and hemicellulase (Sukmadjaja et al. 2007)

On the other hand, the commercial enzyme is inefficient to be used in industry or agriculture because of its high price. One of them is using cellulase purified from cellulolytic bacteria. Pure cellulase from bacteria is easy to develop because it comes 
from cellulolytic bacteria which can be cultivated through cell culture. Therefore the price of bacteria cellulase will be lower than commercial cellulase.

Our previous study has isolated eight cellulolytic bacteria from the digestive tract of milkfish (Lathifah et al. 2009). However, these cellulolytic bacteria has not identified yet. Hence it is important to reveal that these bacteria are belong to cellulolytic bacteria. Among isolated bacteria, crude cellulase extract of BSA B1 cellulolytic bacteria showed highest enzyme activity at $0.35 \mathrm{U} \mathrm{mL}^{-1}$. The activity of this cellulase to degrade the $\mathrm{CMC}$ was optimum at $\mathrm{pH} 9$ and $50^{\circ} \mathrm{C}$. The highest enzyme activity was reached by purification with ammonium sulfat at $60 \%$ saturation, with the volume of $0.26 \mathrm{U} \mathrm{mL}^{-1}$ (Muhammad et al. 2012).

Purification of enzymes is an important stage after the enzyme was isolated (Juhana, 2011). Enzyme purification can be done in various ways such as by precipitation using organic salts, dialysis, and ion exchange chromatography. In addition, to examine the efficacy of purified cellulase, it is necessary to incubate cellulases in cellulose substrate.

The objective of this study were to identify the cellulolytic bacteria BSA B1, purify cellulase from BSA B1 isolate and examine ability of this cellulase to hydrolyze cellulose as compared to commercial cellulase. The substrate was C. zofingiensis and CMC. Chlorella is a natural food of fish that is used as a source of microalgae. Hence, the cellulase is expected to degrade complex cellulose on Chlorella. At this stage, we calculated dry weight and cells biomass of C. zofingiensis and compared the ability of purified cellulase and commercial cellulase (Celluclast $\left.{ }^{\circledR}\right)$ to hydrolyse cellulose in C. zofingiensis.

\section{Materials and Methods}

Medium cultivation of C. zofingiensis was fuel $3 \mathrm{~N}+$ modified vitamin. The substrate used in the degradation is $C$. zofingiensis Dönz (1934). Cellulase that used is cellulase purified from bacteria BSA B1 from milkfish (Chanos chanos) digestive organ and Celluclast ${ }^{\circledR}$ (comercial cellulase). DNA isolation using SDS buffer lysis, chloroform, proteinase and ethanol. Other materials used in analyzing the enzyme activity and protein levels of cellulase and biomass measurement are material for dinitrosalisilat acid reagent (DNS), phosphate buffer $\mathrm{pH} 9$, Bradford reagent and ethanol 95\%. Gel polyacrylamide $10 \%$, aquabidest, running buffer, 10\% APS, TEMED, sample buffer, loading buffer, staining and destaining materials.

\section{Amplification of $16 S$ rRNA Gene}

The cellulolytic bacteria BSA B1 isolate was identified based on $16 \mathrm{~S}$ rRNA gene. The total genomic DNA of cellulolytic bacteria was isolated and purified using the methods as previously described (Ausubel et al. 1995). Pellet of bacteria was resuspended with mixture of lysis buffer and proteinase then precipitated with chloroform. Lysis buffer consisting of $100 \mathrm{mM}$ Tris- $\mathrm{HCl} \mathrm{pH}$ $8,100 \mathrm{mM} \mathrm{NaCl}, 50 \mathrm{mM}$ EDTA, and 1\% SDS . The final stage was washed with $70 \%$ ethanol to obtain DNA from BSA B1. DNA was dissolved in 50 microliters of TE and storage until used. 16S rRNA genes were amplified from bacterial genomic DNA using bacterial universal primers (forward primer 5'-TGGCTCAGAACGAACGCTG GCGGC-3', reverse primer 3'-TACCTTGT TACGACTTCACCCCAGTC-5'). PCR was performed using thermal cycler (Biorad) with $50 \mu \mathrm{l}$ of reaction mixture using PrimeStar GXL polymerase reaction (Takara). PCR cycling condition were, denaturation at $98^{\circ} \mathrm{C}$ for $1 \mathrm{~min}, 30$ cycles of $98^{\circ} \mathrm{C}$ for 10 $\mathrm{s}, 60^{\circ} \mathrm{C}$ for $15 \mathrm{~s}$, and $68^{\circ} \mathrm{C}$ for $130 \mathrm{~s}$ min and the final extension at $68^{\circ} \mathrm{C}$ for $5 \mathrm{~min}$. Amplified product was separated by $1 \%$ agarose gel electrophoresis (Nacalai). The DNA product of the correct size $(1,500$ base pairs) was purified and subjected for sequencing by ABI Prism DNA sequencer. The sequence obtained was aligned by using BLAST analysis (http://www.ncbi.nlm. nih.gov/BLAST) and the phylogenetic tree 
was constructed by MEGA 5.2 (Tamura et al., 2011), using Neighbor Joining statistical method and bootstrap consensus trees inferred from 1,000 permutations of the data sets.

\section{Sample Preparation for Cellulase Purification}

BSA B1 isolates were inoculated on Carboxyl Methyl Cellulose (CMC) media and incubated at room temperature for 2448 hours. Two loops full of pre-incubated bacteria were inoculated into $100 \mathrm{~mL}$ of $1 \%$ CMC liquid medium and incubated in a shaking incubator for 24 hours. Starter inocula was poured into 1\% CMC liquid media and incubated in a shaking incubator for 24 hour. Enzyme was precipitated by centrifugation at a speed of 4,000 rpm for 30 minutes.

\section{Ammonium Sulphate Precipitation}

Ammonium sulphate at various levels of saturation of $60 \%$ (23.04 g) was added into $50 \mathrm{~mL}$ of crude cellulase enzyme while stirring at $4{ }^{\circ} \mathrm{C}$. Then the crude enzyme was incubated at $4{ }^{\circ} \mathrm{C}$ overnight and centrifuged at a speed of 4,000 rpm for 30 minutes. The precipitate obtained was suspended in phosphate buffer $0.01 \mathrm{M} \mathrm{pH} 9$.

\section{Dialysis}

The enzyme was put into dialysis membrane tubing $3 \times 10 \mathrm{~cm}$ and closed by the valve cover dialysis tubing. The dialysis tubing containing enzyme was inserted into $0.01 \mathrm{M}$ buffer phosphate $\mathrm{pH} 9$ and stirred it for 3 hours at a temperature of $4^{\circ} \mathrm{C}$. Then, phosphate buffer was replaced and the membrane tubing containing enzyme was dialyzed overnight in the refrigerator without stirring. Again, phosphate buffer was replaced and dialyzed for 3 hours at 4 ${ }^{\circ} \mathrm{C}$ and stirred.

\section{Ion Exchange Chromatography \\ The cellulase was further purified by DEAE Sepharose Anion Chromatography.}

The column was washed with $5 \mathrm{~mL}$ aquabidest and $5 \mathrm{~mL}$ substrate buffer $(0.025 \mathrm{M}$ Tris buffer $\mathrm{pH} 9) 2$ times. Sample was loaded into the column and then the column was washed with buffer (0.025 M Tris buffer pH 9) two times. Enzyme samples was diluted using elution buffer $(0.025 \mathrm{M}$ Tris buffer $\mathrm{pH} 9$ plus $1 \mathrm{M} \mathrm{NaCl}$ in the ratio $1: 1$ ) about $5 \mathrm{~mL}$.

\section{Examination of Cellulase Enzyme Activity and Protein Concentration}

At each step of purification, cellulase activity was calculated by using the method of Miller (1959). The protein concentration was measured using the Bradford method. The specific activity was calculated from the enzyme cellulase activity value divided by the protein concentration.

\section{Calculation of Cellulase Molecular Weight}

Purified enzyme was analyzed by SDS-PAGE. Then $15 \mathrm{~mL}$ of purified enzyme was added with $5 \mathrm{~mL}$ of sample buffer (62.5 mM Tris $\mathrm{HCl} \mathrm{pH} 6.8,10 \%$ glycerol, 5\% $\beta$-mercaptoethanol, SDS, and Brom phenol blue). The mixture was heated at $95^{\circ} \mathrm{C}$ for 5 minutes. Samples and marker protein was then applied to $12 \%$ polyacrylamide gel, and then electrophoresed using a running buffer of $0.75 \mathrm{M}$ Tris $\mathrm{HCl}$ for 2.5 hours at 75 volts. Then the results of SDS-PAGE was stained with silver staining.

\section{Preparation of C. zofingiensis}

In C. zofingiensis preparation was used suspension substrate 1\% C. zofingiensis (dry weight) in phosphate buffer $\mathrm{pH}$ 9. The cell density was calculated to determine the number of cells per $\mathrm{mL}$ of dry weight in exponential phase. The number of cells calculated using Haemocytometer Nebauer 1 $\mathrm{mm}$. The cell culture taken $1 \mathrm{~mL}$ suspension then dried it in an oven temperature of $50{ }^{\circ} \mathrm{C}$ until constant weight was reached. Degradation assay used 1\% C. zofingiensis suspension in phosphate buffer $\mathrm{pH} 9$.

Cellulose degradation in C. zofingiensis divided in two treatments: fresh cells 
suspended and dehydrated ethanol. Suspended cells treatment used fresh $C$. zofingiensis culture, then centrifuged at 3,300 rpm for 10 minutes and washed with phosphate buffer $\mathrm{pH} 9$ twice. Pellet was resuspended with phosphate buffer $\mathrm{pH} 9$ to obtain a suspension substrate $1 \%$ (dry weight of $1 \mathrm{~mL} \mathrm{C}$. zofingiensis $0.015 \mathrm{mg}$ ) and stored in a freezer as a stock.

In ethanol dehydration treatment, C. zofingiensis cell culture was taken then centrifuged at 3,300 rpm for 10 minutes and washed with 95\% ethanol twice. Pellet was transferred into a porcelain cup and dried by cooling and crushed to a powder. Then, C. zongifiensis powder stored in a freezer as a stock.

\section{Degradation of C. zofingiensis}

Degradation of $C$. zofingiensis was done by purified cellulase from bacteria milkfish (Chanos chanos) BSA B1 (without dilution) and $1 \%$ Celluclast ${ }^{\circledR}(0.01 \mathrm{~mL}$ in $1 \mathrm{~mL}$ of phosphate buffer $\mathrm{pH}$ 9) used as a positive control enzyme. Fresh suspended cells were taken each $1.5 \mathrm{~mL}$ suspensions of $C$. zofingiensis and added $1.5 \mathrm{~mL}$ of cellulase. Treatment of ethanol dehydration was done by taken each 0.015 grams of powdered C. zofingiensis and suspended in $1.5 \mathrm{~mL}$ of phosphate buffer. Then added $1.5 \mathrm{~mL}$ cellulase in each suspension and incubated for 24 hours at a temperature of $50^{\circ} \mathrm{C}$ with the measurement of enzyme activity at $0,4,12,20$, and 24 hours. In these tests, also conducted testing of CMC 1\% as positive controls cellulotic substrates using both cellulases. After a 24 hour incubation, $C$. zofingiensis degradation was observed under a light microscope at 100x magnification to see the condition of the cells that have been degraded.

\section{Results and Discussion}

Previous study indicated that one strain of the cellulolytic bacteria isolated from tractus digestivus of milkfish, namely BSA B1 showed a highest potency to degrade cellulose compare to other strain. We identified this isolate based on 16S rRNA gene sequence.

BSA B1 included in the same cluster with a strain of B. licheniformis strain CCMMB8 accesion number HG80002.1 with a similarity of $98.24 \%$ and B. aerius strain CCMMB776 accesion number KF879292.1 with similarity of $96.54 \%$ (Figure 1). It showed that BSA B1 isolate had a higher level of concordance with B. licheniformis compared to B. aerius. Almost of $B$. licheniformis was isolated from soil and it can be isolated from various places because of its high ability to produce endospores. Milkfish have a habit to eat detritus that may contain microorganisms that assist for detritus digestion (Aslamsyah, 2012).

Cellulase activity cannot be found in milkfish Chanos chanos (Chiu and Benitez, 1981), but other studies found the microbial cellulase activity in the digestive tract of herbivorous fish, especially milkfish (Bairagi et al. 2002). This data was supported by Das et al. (2014) that detect the presence of cellulolytic microbes in the digestive tract of four brackish water fish species. Three of them, including Etroplus suratensis, Scatophagus argus and Terapon jarbua are kind of omnivorous fish that eat algae as well as milkfish. B. parabrevis and $B$. licheniformis were identified from Mystus gulio fish. In addition, Prayitno et al. (2014) identified Shewanella upenei, Bacillus sp, Vibrio fluvialis, Shewanella algae, Shewanella sp., and Photobacterium ganghwense in the digestive tract of sea bass.

Furthermore, we examined the specific activity of purified enzyme of BSA B1. BSA B1 bacteria that used for this study was subcultured from previous study. Our previous study have successfuly isolated some strains from tractus digestivus of milkfish. BSA B1 strain have the highest enzyme activity for cellulose degradation compared to other strains.

Firstly we purified cellulase and analyze enzyme activity in each step. Result showed the highest enzyme activity was cellulase purified by DEAE sepharose chromatography (Table 1). 
The crude enzyme has a lowest enzyme activity compared to purified enzyme. This result probably caused by other biomolecules contained in the crude enzyme which inhibits enzyme to degrade cellulose. Purification started with ammonium sulphate precipitation. Ammonium sulphate precipitation conducted by using basic principle of protein dehydration that is some water molecules are bound to $\mathrm{SO}_{4}^{-2}$ thus reducing the amount of water available to interact with the enzyme (Dobrev and Zhekova, 2012). Ammonium sulphate precipitation performed at $60 \%$ saturation

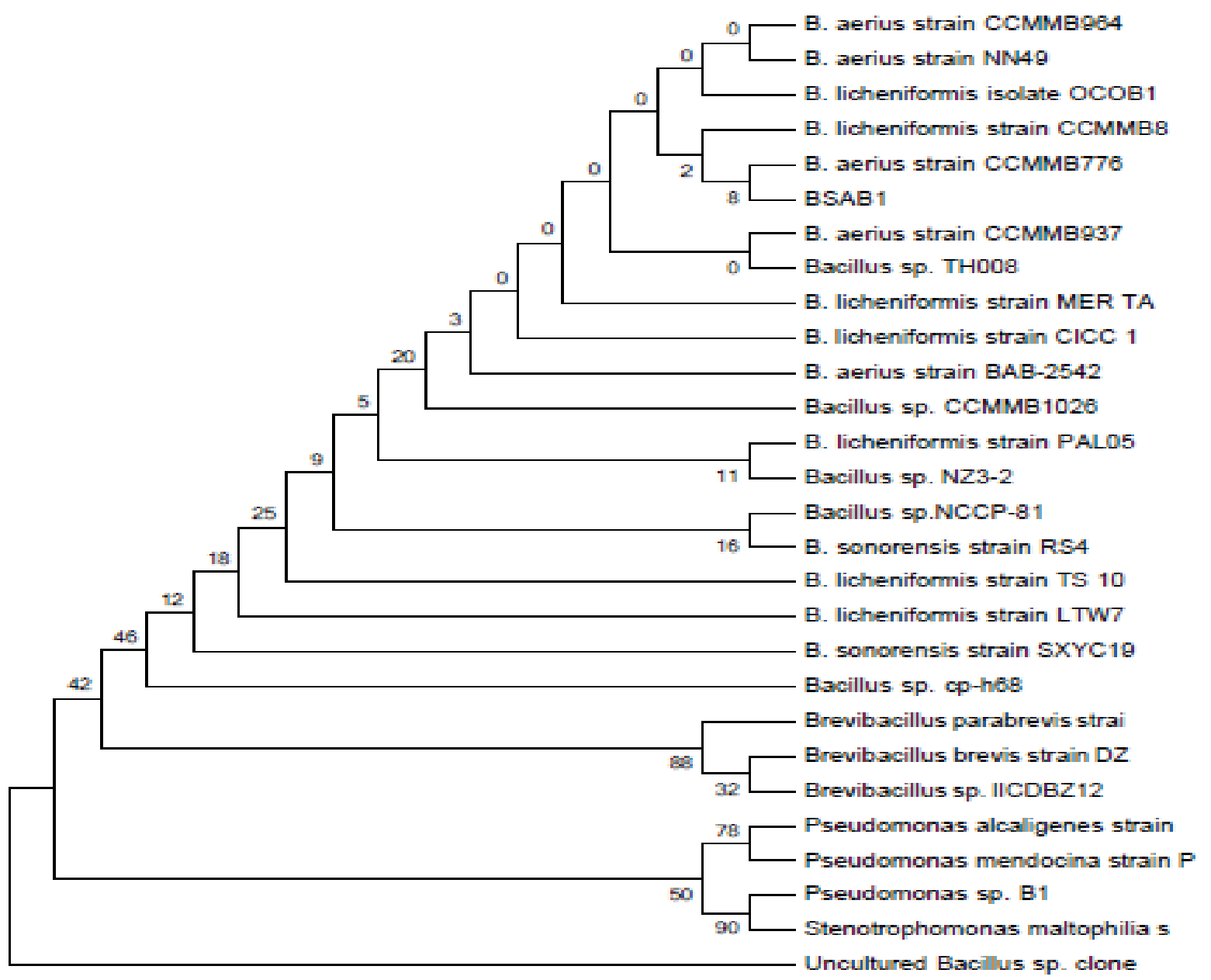

Figure 1. Reconstruction of phylogenetic trees consensus cellulolytic bacterial BSA B1 based on 16S rRNA gene sequences. The evolutionary history was inferred using the Neighbor-Joining method and bootstrap consensus trees inferred from 1,000 permutations of the data sets.

Table 1.Cellulase specific activity in each step of purification

\begin{tabular}{ccccccc}
\hline Fraction & $\begin{array}{c}\text { Enzyme } \\
\text { Volume }(\mathrm{mL})\end{array}$ & $\begin{array}{c}\text { Total Activity } \\
(\mathrm{U})\end{array}$ & $\begin{array}{c}\text { Total Protein } \\
(\mathrm{mg})\end{array}$ & $\begin{array}{c}\text { Specific Activity } \\
\left(\mathrm{U} \mathrm{mg}^{-1}\right)\end{array}$ & $\begin{array}{c}\text { Results } \\
(\%)\end{array}$ & $\begin{array}{c}\text { Purity } \\
(\mathrm{x})\end{array}$ \\
\hline Crude enzyme & 50 & 9.91 & 5.70 & 1.74 & 100 & 1.00 \\
Dialisis & 5 & 1.13 & 0.25 & 4.61 & 11.40 & 2.65 \\
DEAE Sepharose & 1 & 0.30 & 0.04 & 7.28 & 26.43 & 4.19 \\
\hline
\end{tabular}

*In 30 minutes with molecular weight $1 \mu \mathrm{mol}$ glucose $0.18 \mathrm{mg}$ 
which is the best concentration for reaching the isoelectric point of the enzyme.

Cellulase activity can be inhibited by the binding of protein and ammonium sulphate, therefore in this study, enzyme activity was measured after dialysis. Dialysis was based on the principle of osmosis that was the difference of concentration between protein inside dialysis membrane and buffer reagent concentration outside dialysis membrane. Ammonium sulphate will move along gradient concentration through the membrane until it reaches equilibrium. When ammonium sulphate separated from protein, the enzyme purity increased so enzyme activity can be measured.

Next purification step was column chromatography. In this step, enzyme purification was done by the principle of the mobile phase and stationary phase. The mobile phase of this step was purified cellulase from previous step (dialysis). The purified cellulase will be absorbed by stationary phase (DEAE Sepharose) while soluble components which were less absorbed will move faster. During the separation process, the solutes undergo adsorption and partition repeatedly. Each solute has a different decreasing rate and it depends on solute partition coefficient. Hence, several layers are formed (Bakare, 2005)

Table 1 showed that each purification step resulted in purer enzyme. The enzyme concentration decreased while enzyme activity increased. Many contaminant proteins probably found in the crude enzyme which increases protein concentration. However, with the high concentration of protein, enzyme activity became less specific to the substrate.

Molecular weight measurement of purified cellulase showed in Figure 2. Thin protein bands appear because protein content in cellulase decreasing after purification.

The crude enzyme formed three bands with molecular weights of each of them about $59.06 \mathrm{kDa}, 54.34 \mathrm{kDa}$, and $40.6 \mathrm{kDa}$.

Cellulase after ammonium sulfate precipitation, dialysis, and chromatography

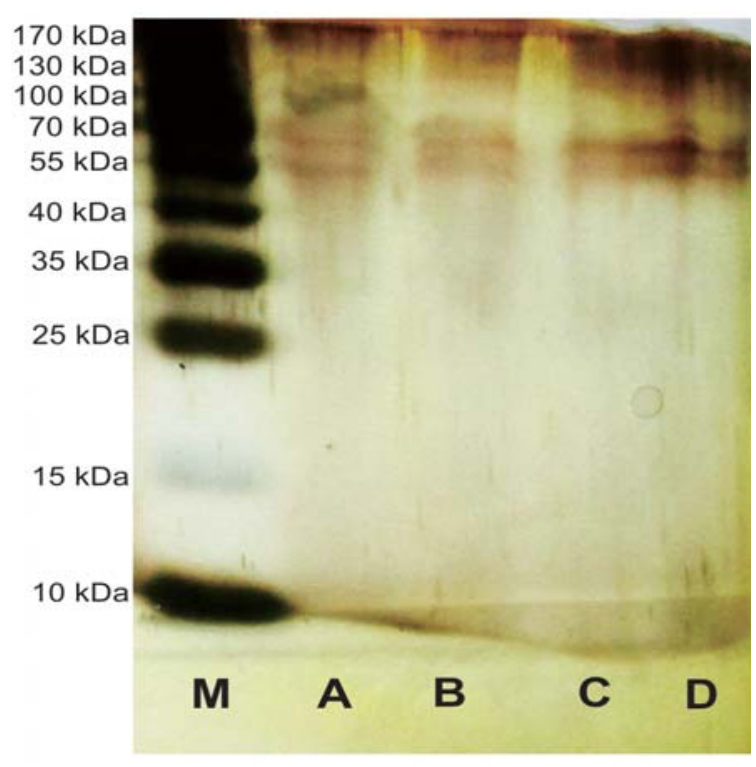

Figure 2. Protein bands appeared in SDS-PAGE gel. (M) is marker protein while number (A) is crude enzyme, (C) is enzyme after ammonium sulfate precipitation, (E) is enzyme from dialysis, (D) is enzyme from chromatography

produced two bands with molecular weight about $59.06 \mathrm{kDa}$ and $54.34 \mathrm{kDa}$. The type of cellulase can be determined by comparing molecular weight with some references about cellulase from microorganisms. These prediction can be seen in Table 2 .

According to table 2, our purified cellulase was possibly contained of endoglucanase, cellobiohydrolase, and $\beta$-glucosidase.

Figure 3 showed specific cellulase activity yields againts C. zofingiensis. Celluclast $^{\circledR}$, a commercial cellulase showed lower specific enzyme activity than our purified cellulase. Specific enzyme activity on the incubated substrate at $1 \%$ Celluclast $^{\circledR}$ was $0.0478 \mathrm{U} \mathrm{mg}^{-1}$ in CMC, whereas our purified cellulase showed specific enzyme activity was $0.7706 \mathrm{U} \mathrm{mg}^{-1}$ in C. zofingiensis dehydrated ethanol. Low specific cellulase activity at $1 \%$ Celluclast $^{\circledR}$ possibly because of its high protein concetration. At 1\% Celluclast ${ }^{\circledR}$, protein concentration was higher than purified cellulase which was $1.035 \mathrm{mg}$ $\mathrm{mL}^{-1}$, and $0.041 \mathrm{mg} \mathrm{mL}^{-1}$ respectively. Thus 
Tabel 2. The molecular weight of purified cellulase.

\begin{tabular}{|c|c|c|c|}
\hline $\begin{array}{c}\text { Molecular weight of } \\
\text { purified enzyme (kDa) }\end{array}$ & $\begin{array}{c}\text { Molecular } \\
\text { weight } \\
\text { references }(\mathrm{kDa})\end{array}$ & Cellulase group & References \\
\hline & $20-60$ & Common cellulase & Rosenberg, 2005. \\
\hline & 22.8 & Endoglucanase V & Bakare et al. 2005 \\
\hline & 23.5 & $\beta$-1,4-glucanase & Bakare et al. 2005 \\
\hline & 25.1 & Endoglucanase VII & Bakare et al. 2005 \\
\hline 28,3 & 26,9 & Endoglucanase & Dobrev and Zhekova, 2012 \\
\hline \multirow[t]{3}{*}{31,$5 ; 53,4$} & $30-55$ & Endoglucanase & Pol et al. 2012 \\
\hline & 33.4 & Endoglucanase IV & Bakare et al. 2005 \\
\hline & 42.2 & Endoglucanase II & Bakare et al. 2005 \\
\hline 45,6 & 46.0 & Endoglucanase I & Bakare et al. 2005 \\
\hline 48,1 & 47.2 & $\beta$-Glucosidase I & Bakare et al. 2005 \\
\hline \multirow[t]{2}{*}{53,$4 ; 54,4$} & 52.1 & Endoglucanase IV & Bakare et al. 2005 \\
\hline & 52.2 & Cellobiohydrolase I & Bakare et al. 2005 \\
\hline 66,1 & 75.3 & $\beta$-glucosidase II & Bakare et al. 2005 \\
\hline
\end{tabular}

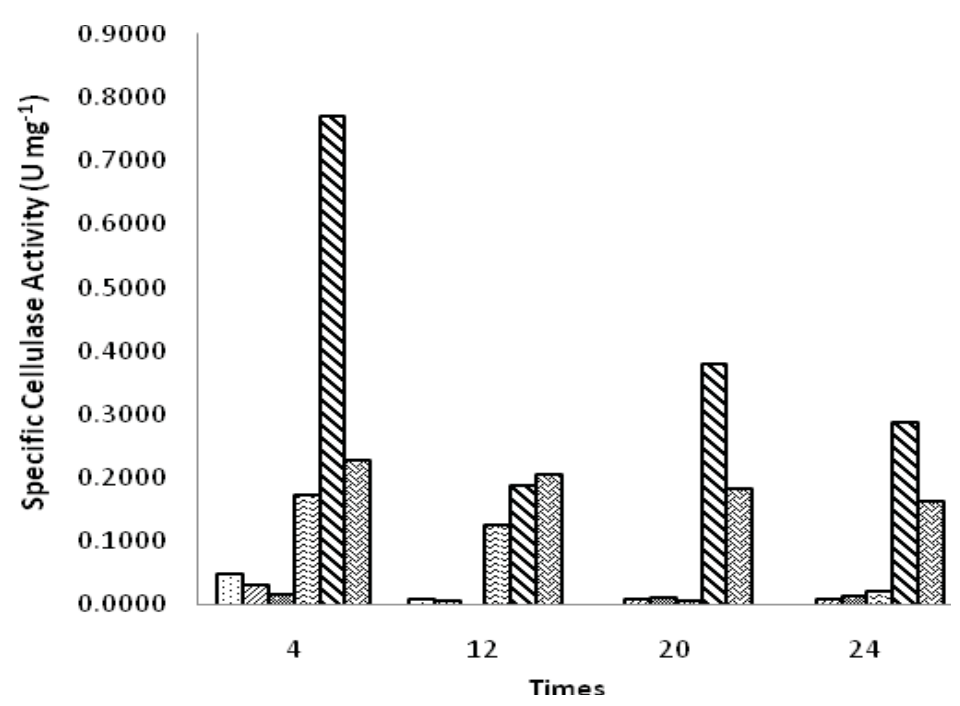

Figure 3. Specific cellulase activity yields of C. zofingiensis per cell (U $\left.\mathrm{mg}^{-1}\right)$. $\mathrm{CMC}$ incubated with $1 \%$ Celluclast $^{\circledR}$, Ethanol-dehydrated $^{\circ}$ C. zofingiensis incubated with $1 \%$ Celluclast ${ }^{\circledR}, \square$ Fresh suspended C. zofingiensis incubated with $1 \%$ Celluclast ${ }^{\circledR}, \mathbf{Q}$ Ethanol-dehydrated C. zofingiensis incubated with purified cellulase $\mathbf{0}$ CMC incubated with purified cellulase $\square$ Fresh suspended C. zofingiensis incubated with purified cellulase.

specific activity of $1 \%$ Celluclast ${ }^{\circledR}$ was much lower than purified cellulase.

Figure 4 showed that the amount of reducing sugar produced by CMC after being incubated with $1 \%$ Celluclast ${ }^{\circledR}$ showed the highest curve whereas CMC incubated with our purified cellulase had the lowest curve among other treatments. In the treatment of $1 \%$ C. zofingiensis incubated with $1 \%$ Celluclast $^{\circledR}$ showed a curve that was lower than the CMC curve. However, the pattern of the curves were not differ between treatment groups. The optimum time of CMC incubated with $1 \%$ Celluclast $^{\circledR}$ to produce reducing sugar detected after 4 hours while the CMC incubated with 


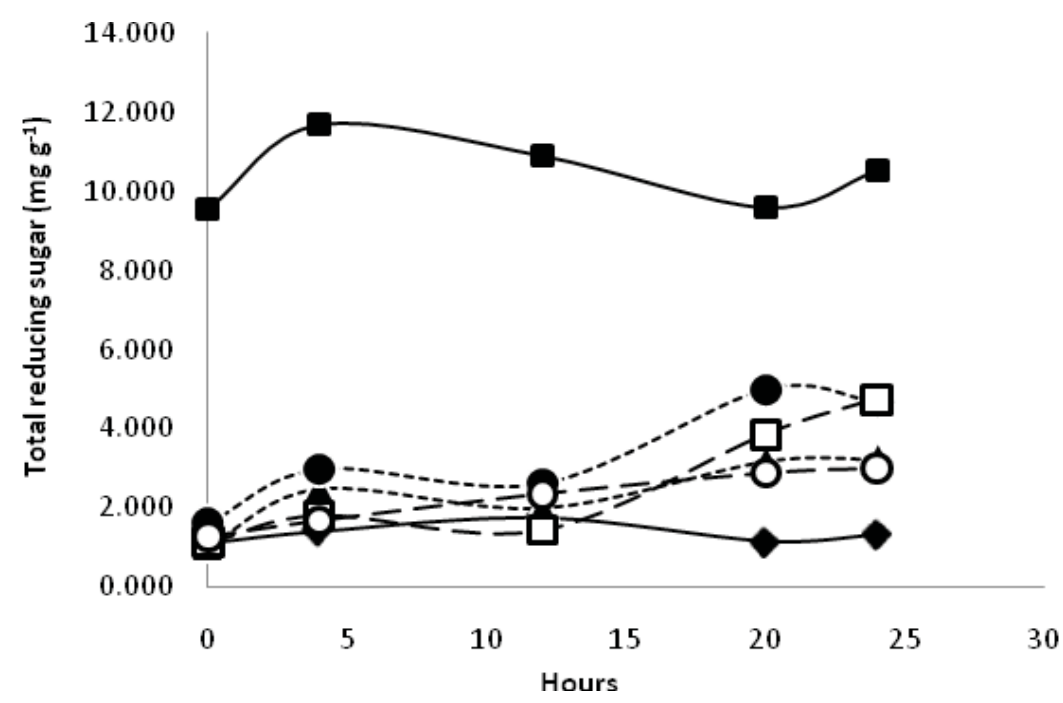

Figure 4. Total reducing sugar yields $\left(\mathrm{mg} \mathrm{g}^{-1}\right)$ of $C$. zofingiensis per $1.5 \mathrm{mg}$ of dried biomass by purified cellulase. $\rightarrow-\mathrm{CMC}$ incubated with $1 \%$ Celluclast, $\longrightarrow-$ CMC incubated with purified cellulase, -----Ethanol-dehydrated C. zofingiensis incubated with $1 \%$ Celluclast $^{\circledR},--\cdot--$ Ethanol-dehydrated C. zofingiensis incubated with purified cellulase, $-\square-$ Fresh suspended C. zofingiensis incubated with $1 \%$ Celluclast ${ }^{\circledR},-\mathbf{O}-$ Fresh suspended C. zofingiensis incubated with purified cellulase.

purified cellulase detected in 12 hours. Furthermore in C. zofingiensis all the optimum treatment detected in 24 hours, except ethanol dehydrated C. zofingiensis incubated in purified cellulase which was detected after 20 hours of treatment.

Figure 5 showed that the morphology of the cells changed after enzyme incubation and ethanol dehydration treatment. The addition of ethanol possibly caused $C$. zofingiensis cells were dehydrated and destructed before incubation with cellulase. Incubation with cellulase caused cells were destroyed so we found cell debris while intact cells has not detected. On the other hand incubation of cellulase without ethanol dehydration caused C. zofingiensis lose their cell wall. However a cell membrane still detected whereas the cytoplasm were swollen and formed as morphology similar to protoplasts (pointed with arrow). This condition could be affected by cellulase degrades the cell wall of C. zofingiensis, hence the cells become rigid and form structures similar to protoplasts.
According to enzyme activity and protein concentration measured at each stage of purification showed that in every step our cellulase getting purer, the enzyme concentration decreased, and enzyme activity increased. Furthermore purified cellulase have a molecular weight ranging from 20 to $60 \mathrm{kDa}$. Less band detected in chromatographic purification stage compare to crude enzyme showed that cellulase getting purer. In this study we used Celluclast ${ }^{\circledR}$, a commercial cellulase, as a reference. The activity of commercial cellulase was too high so it cannot be read by spectrophotometer (unpublished data). Thus, we used 1\% Celluclast ${ }^{\circledR}$ which predicted had similar activity with our purified cellulase. According to SDS PAGE, Celluclast ${ }^{\circledR}$ possibly mainly contains endoglucanase (CMCase) also exoglucanase and $\beta$-glucosidase in lower concentration.

Purified cellulase had cellulolytic activity on CMC. CMC was pure cellulose modified by the addition of carboxyl groups and has been known as a substrate to test celulase 


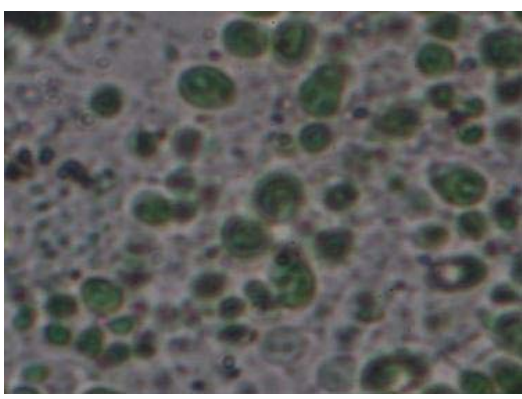

(a)

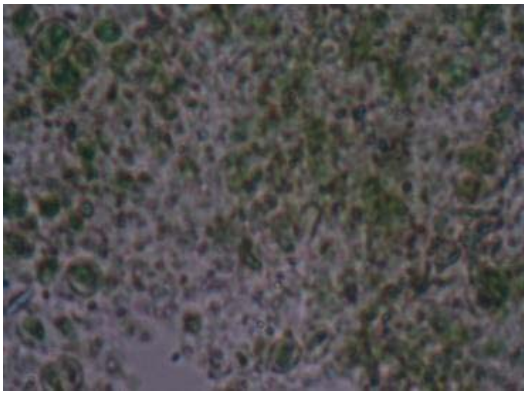

(d)

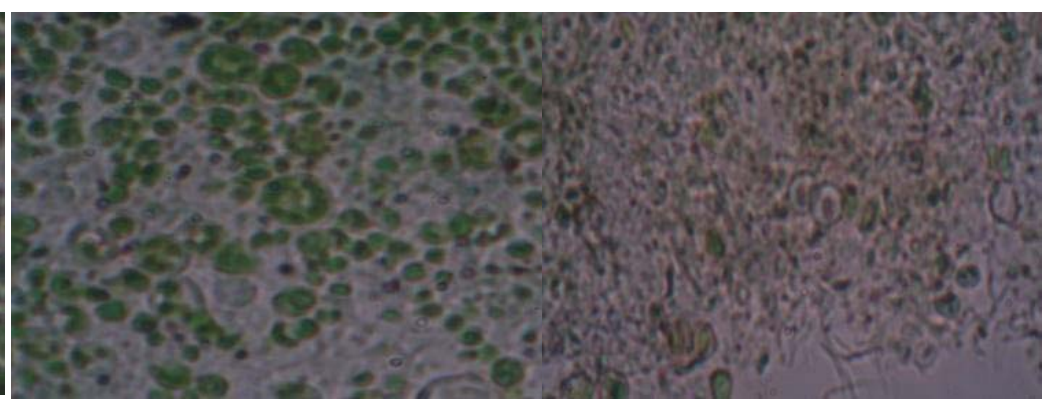

(b)

(c)

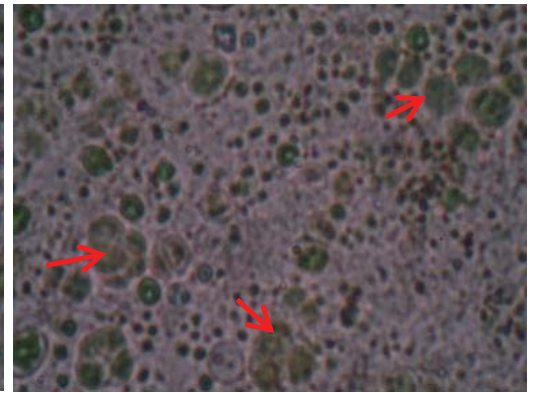

(e)

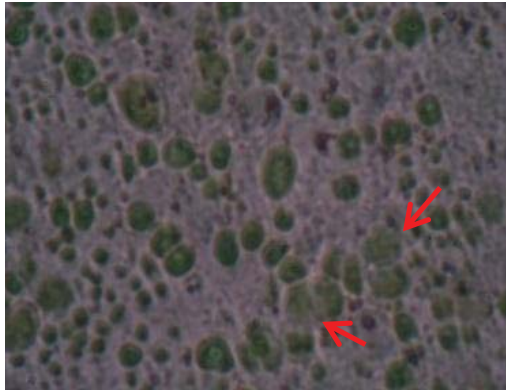

(f)

Figure 5. Comparison of C. zofingiensis cell morphology at several treatments after incubating for 24 hours (a), (b) normal cell; (c) $1 \%$ Celluclast $^{\circledR}$ and ethanol treatments; (d) Cellulase treatment from purification and ethanol; (e) $1 \%$ Celluclast ${ }^{\circledR}$ treatment; (f) Purified Cellulase from this study.

activity. In various studies, CMC is known as substrate-specific against endoglucanase, so it is also called the endoglucanase CMCase. On the other hand, C. zofingiensis is a microalgae that developed in many industries. This microalgae is known to have high cellulose content and high potential to be degraded by cellulase from the group $\beta$-glucosidase (Rodrigues et al., 2015) using C. homosphaera which has a composition similar to $C$. zofingiensis). Results showed that our purified cellulase had lower activity on CMC but higher activity in C. zofingiensis compare to 1\% Celluclast. These data revealed that our purified cellulase contains different type of cellulase with Celluclast ${ }^{\circledR}$. The content of endoglucanase in 1\% Celluclast ${ }^{\circledR}$ possibly suitable for hydrolyzing CMC so that its activity was higher while the content of $\beta$-glucosidase is possibly dominant in our purified cellulase which more appropriate to degrade the component of $C$. zofingiensis cell wall.
Fresh cells was used as model to determined ability of enzyme to produce single cell protein whether ethanol dehydrated cells was used as a model of bioethanol production. Ethanol was used because it can destabilize outer cell walls of algae. This condition would facilitate the cellulase to hidrolyze ultrastructure cellulose of the cell. Hydrolyzed cellulose was expected to raise the amount of resulted reducing sugars. However, our results showed that ethanol was only able to raise the amount of reducing sugar if it was incubated with purified cellulase, whereas in $1 \%$ Celluclast ${ }^{\circledR}$, ethanol lowering the amount of reducing sugar. This indicated that ethanol can increase the amount of reducing sugar when used appropriate cellulase.

C. zofingiensis cell walls contain cellulose that can be hydrolyzed by purified cellulase and $1 \%$ Celluclast ${ }^{\circledR}$. Fresh cell incubated with cellulases showed that the cell wall of $C$. zofingiensis was successfully hydrolyzed by 
both cellulases with the loss of the cell wall whereas cell membrane still intact to form structures such as protoplasts. However, the ethanol treatment caused cells have been destroyed prior cellulase incubation. Hence, in ethanol treatment cells intact were not detected.

\section{Conclusion}

BSA B1 strain was closely related with $B$. aerius and B. licheniformis. Cellulase from BSA B1 bacteria was successfully purified. The crude enzyme formed three bands with molecular weights of each of them about 59.06 $\mathrm{kDa}, 54.34 \mathrm{kDa}$, and $40.6 \mathrm{kDa}$. The results of ammonium sulfate precipitation, dialysis, and chromatography produced two bands with molecular weight about $59.06 \mathrm{kDa}$ and $54.34 \mathrm{kDa}$. Purified cellulase had an activity to hydrolize CMC and C. zofingiensis Dönz. Morphology of C. zofingiensis Dönz cells on ethanol dehydration and cellulase incubation showed that the cells collapsed. Fresh cell incubated with cellulases showed that the cell wall of C. zofingiensis was successfully hydrolyzed by both cellulase with the loss of the cell wall whereas cell membrane are still intact. However in ethanol treatment cells intact were not detected.

\section{Acknowledgment}

This study was financially supported by PKM-P 2014 Higher Education grants. Publication was supported by BPP UGM Grant 2015.

\section{References}

Aslamsyah, S. 2012. Seleksi mikroflora saluran pencernaan ikan bandeng sebagai kandidat probiotik (Selection of gastrointestinal microflora in milkfish as probiotic candidate). Department of Fisheries, Faculty of Marine Science \& Fisheries. Hasanuddin University. Makassar. [In Bahasa].

Ausubel, F.M., Brent, R., Kingston, R.E., Moore, D.D., Seidman, J.G., Smith, J.A. and Struhl, K. 1995. Short Protocols in
Molecular Biology. John Wiley \& Sons. New York

Bairagi, A., Ghosh, K.S., Sen, S.K., and Ray, A.K.. 2002. Enzyme producing flora isolated from fish digestive tracts. Aquaculture Internationa, l 10, 109-121.

Bakare, M.K., Adewale, I.O., Ajayi, A., and Shonukan, O.O. 2005. Purification and characterization of cellulase from the wild-type and two improved mutants of Pseudomonas fluorescens. African Journal of Biotechnology, 4(9), 898-904.

Dobrev, G.T. and Zhekova, B.Y. 2012. Biosynthesis, purification and characterization of endoglucanase from a xylanase producing strain Aspergillus niger B03. Braz. J. Microbiol., 43(1), 70-77.

Das, P., Mandal, S., Khan, A., Manna, S.K., and Ghosh, K. 2014. Distribution of extracellular enzyme-producing bacteria in the digestive tracts of 4 brackish water fish species. Turk J Zool., 38, 79-88.

Hidayanti, A.K. 2011. Isolasi bakteri amilolitik dari Chlorophyta (Amylolytic bacteria isolation from Chlorophyta). Thesis, (S.Si.). Fakultas Biologi UGM. Yogyakarta. [In Bahasa].

Juhana, N. 2011. Karakterisasi enzim amilolitik isolat bakteri amilolitik yang berasosiasi dengan Chlorophyta (Characterization of amylolytic enzyme of isolate amylolytic bacteria associated with Chlorophyta). Thesis, (S.Si.). Fakultas Biologi UGM. Yogyakarta. [In Bahasa].

Lathifah, A. N., Hidayanti, A.K., and Ramadingrum, W. A.. 2009. Isolasi bakteri selulolitik dari lambung ikan bandeng (Isolation of cellulolytic bacteria from Milkfish gastrointestinal). Fakultas Biologi UGM. Yogyakarta. [In Bahasa].

Mäntylä, A., Paloheimo, M., and Suominen, P. 1998. Industrial mutants and recombinant strain of Trichoderma reesei. In: Kubicek CP, Harman GE, Ondik KL, editors. Trichoderma and Gliocladium, Enzymes, biological control, and commercial applications. London: Taylor \& Francis; 1998. 291-309. Chapter 13. 
Muhammad, F. B., Pramana, A.A., and Pertiwi, G.A. 2012. Purifikasi enzim selulase isolat bakteri selulolitik yang berpotensi sebagai agen biokatalisator pada berbagai bidang industri pengguna selulosa (Purification of sellulolytic enzyme from isolate cellulolytic bacteria with potency as biocatalisator agent in various cellulose-used industries). Research report. Fakultas Biologi UGM. Yogyakarta. [In Bahasa].

Pol, D., Laxman, R.S. and Rao, M. 2012. Purification and biochemical characterization of endoglucanase from Penicilium pinophilum MS 20. Indian Journal of Biochemistry and Biophysics 49, 189-194.

Prayitno, S.B., Sarwan, and Sarjito. 2014. The diversity of gut bacteria associated with Milkfish (Chanos chanos Forssksal) from northern coast of Central Java, Indonesia. Procedia Environmental Sciences. 23 (2015), 375-384.

Rosenberg, I.M. 2005. Protein analysis and purification. Second edition. Birkhauser. USA: 143.

Sukmadjaja, D.N., Sunarlim, E.G., Lestari, I., Roostika, and Suhartini, T. 2007. Teknik isolasi dan kultur protoplas tanaman padi (Isolation technique and protoplast culture of rice plant. Jurnal Agrobiogen, 3(2), 60-65. [In Bahasa].

Tamura, K., Peterson, D., Peterson, N., Stetcher, G., Nei, M, and Kumar, S. 2011. MEGA5: Molecular evolutionary genetics analysis using maximum likelihood, evolutionary distance, and maximum parsimony methods. Mol. Biol. Evol., 28(10), 2731-2739. 